PRZEGLĄD RUSYCYSTYCZNY 2019, nr 3 (167)

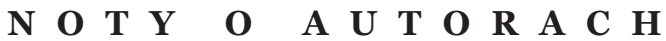

\section{IRINA BIEŁOBROWCEWA}

profesor literatury rosyjskiej na Uniwersytecie w Tallinie, autorka książek i artykułów na temat literatury i kultury rosyjskiej XX i XXI wieku, literatury estońskiej i stosunków literackich między Rosją a Estonią. Najważniejsze publikacje: Конструктивные принципы организации текста романа Михаила Булгакова «Мастер и Маргарита» (Tartu, 1997); Роман М. Булгакова «Мастер и Маргарита: Опыт комментария (Tallinn, 2004; współautorstwo S. Kulius); Роман М. Булгакова «Мастер u Маргарита»: Комментарий (Tallinn, 2007; współautorstwo S. Kulius); Роман М. Булгакова «Мастер и Маргарита»: Комментарий (współautorstwo S. Kulius; Moskwa, 2007); Образ «малого врага»: Прибалтика и Польша в зеркале советской карикатуры (1918-1940) (Moskwa, 2013; współautorstwo D. Wsewiow i A. Danilewski).

Kontakt: venefil@tlu.ee

ORCID: 0000-0002-1619-4642

\section{JEWGIENIJ JABŁOKOW}

Doktor habilitowany nauk filologicznych, pracownik naukowy Instytutu Slawistyki Rosyjskiej Akademii Nauk. Autor książek Мотивы прозы Михаила Булгакова (1997), Роман Михаила Булгакова «Белая гвардия» (1997), На берегу неба: Роман Андрея Платонова «Чевенгур» (2001), Художественный мир Михаила Булгакова (2001), Текст и подтекст в рассказах М. Булгакова: «Записки юного врача» (2002), Нерегулируемые перекрестки: О Платонове, Булгакове и многих других (2005), Роман Александра Грина «Блистающий мир» (2005), Михаил Булгаков и мировая культура: справочник-тезаурус (2011), А.С. Грин в жизни и творчестве (2012), Хор солистов: Проблемы и герои русской литературы первой половины ХХ века (2014), Подвал мастера. М.А. Булгаков: поэтика и культурный контекст (2018) oraz innych prac literaturoznawczych.

Kontakt: eajablokov@gmail.com

ORCID: 0000-0002-7926-1689 


\section{ALEKSANDER KIKLEWICZ}

Pracuje w Instytucie Dziennikarstwa i Komunikacji Społecznej Uniwersytetu Warmińsko-Mazurskiego w Olsztynie. Kierownik Zakładu Komunikacji Społecznej i Języka Mediów. Dyrektor Centrum Badań Europy Wschodniej UWM w Olsztynie. Redaktor naczelny czasopisma „Przegląd Wschodnioeuropejski”. Redaktor trzech serii wydawniczych. Autor ponad 450 publikacji, w tym 21 monografii. Publikował w wielu językach i w wielu krajach. Przedmiotem zainteresowań jest teoria i filozofia języka, metodologia badań lingwistycznych, socjologia językoznawstwa, gramatyka funkcjonalna, składnia semantyczna, komunikologia i pragmatyka językowa, psycholingwistyka i semantyka kognitywna, semantyka logiczna, językoznawstwo konfrontatywne: polsko-wschodniosłowiańskie oraz słowiańsko-germańskie. Kierownik bądź wykonawca kilku projektów naukowo-badawczych, w tym realizowanych we współpracy międzynarodowej. Jest członkiem Komisji Stylistycznej oraz Komisji Lingwistyki Dyskursu przy Międzynarodowym Komitecie Slawistów, a także członkiem Socjetas Humboldtiana Polonorum. Jest (powtórnie) członkiem Zarządu Polskiego Towarzystwa Językoznawczego. Kontakt: akiklewicz@gmail.com

ORCID 0000-0002-6140-6368

\section{NATALIA ŁUŃKOWA}

Absolwentka katedry języków słowiańskich Wydziału Filologicznego Moskiewskiego Uniwersytetu Państwowego im. Łomonosowa (2011) oraz młodszy pracownik naukowy w Instytucie Slawistyki Rosyjskiej Akademii Nauk (Moskwa) w oddziale literatur współczesnych Europy Środkowej i Południowo-Wschodniej. Zainteresowania badawcze: literatura bułgarska XX-XXI wieku, poetyka bułgarskiej prozy. Publikowała wzbiorach Художественный перевод и его роль в литературном процессе Центральной и ЮгоВосточной Европы (2016), Вектор поп-fiction в современных литературах Центральной и Юго-Восточной Европы (2018).

Kontakt: lunkova_n@mail.ru

ORCID: 0000-0001-9193-3890

\section{BARTOSZ OSIEWICZ}

Dr hab., adiunkt w Zakładzie Literatury Rosyjskiej Instytutu Filologii Rosyjskiej i Ukraińskiej Uniwersytetu im. Adama Mickiewicza w Poznaniu. Autor monografii Интертекстуальность в поэзии Владимира Высоцкого, Poznań 2007; Formy i źródta poezji Aleksandra Galicza, Poznań 2016. Teksty publikował m.in. w takich czasopismach jak „Przegląd Rusycystyczny”, „Slavica Wratislaviensia”, „Studia Rossica Posnaniensia”, „AvtobiografiЯ”, „Mundo Eslavo”, „Rusistika”. „The Journal of the Korean Association of the Rusists”, „Вестник Волгоградского государственного университета”. Kontakt: osiebar@amu.edu.pl.

ORCID: 0000-0003-2208-5386 


\section{GRZEGORZ PRZEBINDA}

Filolog rusycysta i historyk idei, wieloletni dyrektor instytutu Filologii Wschodniosłowiańskiej UJ, od 2005 kierownik Katedry Kultury Słowian Wschodnich UJ. Rektor Państwowej Wyższej Szkoły Zawodowej im. Stanisława Pigonia w Krośnie. Autor ponad 300 publikacji, w tym dziewięciu książek na temat kultury i historii Rosji, Ukrainy i Białorusi, także ich związków z Polską. W 1991 uhonorowany Nagrodą Polcul za „współpracę polsko-rosyjską w walce o demokrację". Ostatnia książka - Между Краковом, Римом и Москвой. Русская идея в новой Польше (Moskwa 2013). W 2016 wraz z żoną Leokadią Anną i synem Igorem opublikował autorski przekład Mistrza i Małgorzaty z filologicznym komentarzem. Odznaczony Krzyżem Kawalerskim Orderu Odrodzenia Polski (2015).

Kontakt: gregp6@gmail.com.

ORCID: 0000-0001-9581-0214

\section{NADIEŻDA STARIKOWA}

Doktor nauk filologicznych, kierownik oddziału literatury współczesnej Europy Środkowej i Południowo-Wschodniej w Instytucie Slawistyki Rosyjskiej Akademii Nauk (Moskwa). Zajmuje się problemami współczesnego procesu literackiego. Autor monografii Словенский исторический роман 1920-3о-х годов. Типология, генеалогия, поэтика (2006), Словенская литература XX века (2014), Литература в социокультурном пространстве независимой Словении (2018). Wykładowca w katedrze filologii słowiańskiej na Wydziale Filologicznym Moskiewskiego Uniwersytetu Państwowego im. Łomonosowa.

Kontakt: nstarikova@mail.ru

ORCID: 0000-0003-1230-2244

\section{JEWGIENIJA SZAT'KO}

Absolwentka katedry języków słowiańskich Wydziału Filologicznego Moskiewskiego Uniwersytetu Państwowego im. Łomonosowa (2010) oraz młodszy pracownik naukowy w Instytucie Slawistyki Rosyjskiej Akademii Nauk (Moskwa) w oddziale literatur współczesnych Europy Środkowej i Południowo-Wschodniej. Sfera zainteresowań naukowych: literatura serbska XX-XXI wieku,poetykapowieściserbskiej.Publikowaławzbiorach Хyдожественный перевод и его роль в литературном процессе Центральной $u$ Юго-Восточной Европы (2016), Вектор non-fiction в современных литературах Центральной и Юго-Восточной Европы (2018). Kontakt: eshatko@gmail.com

ORCID: 0000-0001-9467-8987

\section{ALEKSANDER WAWRZYŃCZAK}

Dr hab., adiunkt w Katedrze Kultury Słowian Wschodnich Instytutu Filologii Wschodniosłowiańskiej Uniwersytetu Jagiellońskiego. Historyk litera- 
tury rosyjskiej. Autor monografii: Naród i państwo w twórczości pisarzy rosyjskich nurtu „wiejskiego” (Kraków, 2005), Imperialista, technokrata, mistyk. Twórczość literacka i publicystyczna Aleksandra Prochanowa (Kraków, 2014), a także artykułów poświęconych literaturze rosyjskiej XX i XXI wieku.

Kontakt: aleksander.wawrzynczak@uj.edu.pl

ORCID: 0000-0002-7817-2107

\section{ALICJA WOŁODŹKO-BUTKIEWICZ}

Emerytowana profesor zwyczajna Uniwersytetu Warszawskiego, literaturoznawczyni, członek Komitetu Słowianoznawstwa Polskiej Akademii Nauk. W latach 2002-2012 dyrektor Instytutu Rusycystyki Uniwersytetu Warszawskiego. Autorka ponad dwustu publikacji naukowych oraz artykułów krytycznoliterackich i popularyzatorskich o literaturze rosyjskiej XX i XXI wieku, w tym monografii Pasierbowie Rosji. O prozaikach trzeciej emigracji (Warszawa 1995) i Od pieriestrojki do laboratoriów netliteratury (Warszawa 2004). Tłumaczka prozy rosyjskiej - m.in. Aleksandra Sołżenicyna, Czyngiza Ajtmatowa, Anatolija Gładilina. Opracowała dwie czterotomowe edycje dzieł Michaiła Bułhakowa w Polsce. Nagrodzona Krzyżem Oficerskim Orderu Odrodzenia Polski (2005), nagrodą ZAIKS-u za przekłady literatury rosyjskiej na język polski (2008) i rosyjskim odznaczeniem państwowym „Medal Puszkina” za popularyzację kultury rosyjskiej w Polsce (2013).

Kontakt: atbwo@ids.pl

ORCID: 0000-0002-1848-1581

BOŻENA ŻEJMO

Dr hab., rusycystka i bułgarystka, literaturoznawczyni, adiunkt w Katedrze Filologii Słowiańskiej UMK w Toruniu. Zainteresowania badawcze: etyka i literatura, transgresje w literaturze i kulturze, rosyjsko-bułgarskie związki historyczne i kulturowe, pisarstwo Wsiewołoda Garszyna, mit imperium w literaturze rosyjskiej, mentalność rosyjska, literatura rosyjska wobec władzy totalitarnej. Monografie: Problemy etyczne we wspótczesnej prozie i publicystyce rosyjskiej (lata 60.-90. XX wieku), Łódź 2000; „Ponad stan". Motywy transgresyjne w pisarstwie Jordana Jowkowa, Toruń 2010; Płaczący Ezop. Życie i twórczość Wsiewołoda Garszyna, Toruń 2017. Kontakt: bo.zena@poczta.onet.pl ORCID 0000-0002-2850-6308 


\section{INFORMACJE \\ DOTYCZĄCE ZASAD PUBLIKOWANIA MATERIAŁÓW W NASZYM KWARTALNIKU}

Wszystkich zainteresowanych opublikowaniem prac w „Przeglądzie Rusycystycznym” prosimy o zapoznanie się z Zasadami przygotowania tekstów do druku zamieszczonymi na stronie internetowej naszego kwartalnika - http://www.journals.us.edu.pl/index. $\mathrm{php} / \mathrm{PR} /$ about/submissions\#authorGuidelines.

Wersja elektroniczna „Przeglądu” jest publikowana na platformie czasopism Uniwersytetu Śląskiego http://www.journals.us.edu.pl/index.php/PR, gdzie zostały także zamieszczone (w zakładce Archiwum) poprzednie edycje pisma z ostatnich kilkunastu lat, a także wszelkie szczegóły dotyczące zasad kwalifikowania prac do druku, wykaz recenzentów itp. Numery archiwalne „Przeglądu Rusycystycznego” są także zamieszczone w bazie CEEOL (Central and East European Online Library). Nasze pismo jest indeksowane w bazie ERIH+ oraz umieszczone w wykazie czasopism naukowych Ministerstwa Nauki i Szkolnictwa Wyższego (11 punktów).

Teksty do publikacji (artykuły, recenzje, omówienia, polemiki itp.) należy składać wyłącznie poprzez stronę naszego czasopisma po zarejestrowaniu się na niej w charakterze autora i czytelnika. Zgodnie z odpowiednim formularzem prosimy o załączanie tam streszczeń (polskiego, rosyjskiego i angielskiego wraz z tytułami), bibliografii oraz skrótowego biogramu autora. Wszelkie ilustracje (diagramy wykresy) proszę dołączać w osobnych plikach w formacie jpg z rozdzielczością 300 dpi w odcieniach szrości (nie drukujemy ilustracji kolorowych!),

Redakcja zastrzega sobie prawo odrzucania tekstów niespełniających przyjętych w „Przeglądzie” kryteriów, redagowania i skracania nadesłanych prac (co czynimy zawsze, konsultując te zmiany z PT Autorami).

Teksty nadesłane do naszego pisma recenzowane są anonimowo przez dwóch niezależnych recenzentów zgodnie z zasadami double-blind review. Złożenie prac do druku w naszym piśmiejest równoznacznezwyrażeniem zgody na przyjęty przez nas sposób recenzowania, na opublikowanie ich zarówno w wersji drukowanej, jak elektronicznej, na ujawnienie biogramu i adresu poczty elektronicznej autora. Publikacja w „Przeglądzie Rusycystycznym" nie ogranicza praw autora (osobistych i majątkowych) do opublikowanego tekstu.

Przesłanie tekstu do publikacji jest równoznaczne z oświadczeniem autora o oryginalności pracy i nieograniczonych w żaden sposób jego prawach autorskich do złożonego do publikacji tekstu oraz ewentualnych ilustracji, diagramów, wykresów itp., które to prawa zostają przeniesione na „Przegląd Rusycystyczny” w zakresie jednorazowej publikacji oraz udostępnienia tekstu w formie drukowanej i elektronicznej.

Redakcja „Przeglądu Rusycystycznego” prosi autorów o ujawnianie wkładu poszczególnych osób w powstanie publikacji (z podaniem ich afiliacji oraz określenia rodzaju wkładu, tj. informacji, kto jest autorem koncepcji, założeń, metod, itp. wykorzystywanych przy przygotowaniu tekstu). Istotne jest również podanie informacji o źródłach finansowania publikacji (granty krajowe i zagraniczne, badania statutowe jednostek i in.), wkładzie instytucji naukowo-badawczych, stowarzyszeń i innych podmiotów (financial disclosure). W związku z koniecznością złożenia wraz z tekstem deklaracji o prawach autorskich i oryginalności tekstu, główną odpowiedzialność ponosi autor zgłaszający manuskrypt.

Zgodnie z przyjętymi zasadami etycznymi obowiązującymi w nauce redakcja dba o wysoki poziom merytoryczny kwartalnika oraz wdraża procedury zabezpieczające przed takimi nieetycznymi praktykami podważającymi rzetelność prezentowania rezultatów badań naukowych jak ghostwriting i guest authorship. 